\title{
Robert Boyle on God's 'Experiments': Resurrection, Immortality and Mechanical
}

\section{Philosophy}

by

\author{
Salvatore Ricciardo* \\ Dipartimento di Lettere e Filosofia, Università degli Studi di Bergamo 24121 \\ Bergamo, Italy.
}

This paper explores the origin and the development of Boyle's concern about the proper relationship between his natural philosophy and religion. In particular, it deals with the philosophical problem which mechanical and Christian philosophers had to face: how God operates or might operate in a mechanical world such as theirs. Previous scholars have addressed this issue: Boyle has become exemplary of the dialogue between voluntaristic theology and mechanism. According to such authors, Boyle tried to reconcile his corpuscular hypothesis, an interesting example of the development of mechanism after Descartes' and Gassendi's systematic philosophies, with his own religious beliefs. As Antonio Clericuzio has pointed out, 'Boyle shaped his own version of the mechanical philosophy with the constant concern to avoid all possible conflict between natural philosophy and Christian religion'. ${ }^{1}$ Although Boyle acknowledged that divine activity brought about effects which cannot be explained by size, shape or motion, i. e. the mechanical affections of matter, he did not however place divine activity outside of the natural realm. In this paper I have sought to investigate Boyle's view on God's intervention in the natural world from the perspective of his religious concerns, which focused on the need of evidence supporting the credibility of the Christian religion. In doing this I attempt to offer an interpretation of Boyle's changing views on two issues which were major religious concerns, the immortality of the soul

\footnotetext{
* I am deeply grateful to Prof. Michael Hunter for his valuable comments on an earlier draft of this paper and to Elizabethanne Boran for her helpful suggestions. I wish to thank Prof. Franco Giudice for his advice and Prof. Enrico Giannetto for help and discussions when this paper was in progress.

${ }^{1}$ A. Clericuzio, 'God and the Physical World in Boyle's Thought', in Departure for Modern Europe. Aufbruch in das moderne Europa. A Handbook of Early Modern Philosophy (1400-1700) edited by H. Busche (Hamburg: Felix Meiner Verlag 2011), 1033-1047, 1047. See also J. H. Brooke, Science and Religion. Some Historical Perspectives (Cambridge: Cambridge University Press, 1991), 130-35; M. J. Osler, 'The intellectual sources of Boyle's philosophy of nature: Gassendi's voluntarism and Boyle's physico-theological project', in R. Kroll, R. Ashcraft, P. Zagorin, Philosophy, Science and Religion in England 1640-1700 (Cambridge: Cambridge University Press, 1992), 178-98.
} 
and the resurrection of the dead. In particular, I highlight the role Cartesian philosophy played in Boyle's reflections on the immortality of the soul. Moreover, I attempt to show that there was a significant difference between Boyle's early views on the apologetic function of experiments and what he delivered in his later work on resurrection, a difference which reflects Boyle's commitment to mechanical explanations.

\section{Reason and Experiment in 'Holy Scriptures'}

Boyle's early papers and biographical details suggest that early in his life he became anxious about the immortality of the soul and the resurrection of the dead. Needless to say, Boyle was not alone. During the Interregnum such issues were widely debated among his countrymen. In the 1646 revision of the Thirty-nine Articles the Westminster Assembly, for instance, felt the need to insert an entire chapter devoted to establishing the orthodox view: by death the body decays, returning to dust, and the soul immediately goes to heaven or hell, waiting for the final resurrection or the second and eternal death. ${ }^{2}$ Two years later the Ordinance for punishing blasphemies and heresies (1648) introduced the death penalty for anyone who denied bodily resurrection. ${ }^{3}$ In the 1640s books and pamphlets which contained heterodox views on the fate of soul and resurrection were published or reprinted, such as Richard Overton's Mans Mortalitie (1643). The end of the decade saw also the revival of the Family of Love's views and the spread of sectarians' allegorical interpretations of the Scripture. ${ }^{4}$

At the early stage of his intellectual development Boyle seemed to be anxious about those interpretations, as witnessed by Sir Peter Pett's account of Boyle's participation in

\footnotetext{
${ }^{2}$ The humble Advice of The Assembly of Divines, Now by Authority of Parliament sitting at Westminster, Concerning a Confession of Faith, Presented by them lately to both Houses of Parliament (London, 1646), 52-53. The orthodox view was stated by Calvin in his Psychopannychia (1542). See N. T. Burns, Christian Mortalism from Tyndale to Milton (Cambridge, Mass.: Harvard University Press, 1972), 20-25, 143.

${ }^{3}$ An ordinance of the Lords and Commons assembled in Parliament, for the punishing of blasphemies and heresies: with the severall penalties therein expressed (London: John Wright, 1648), sig. A3r.

${ }^{4}$ For an account of sectarian views on the soul see N. T. Burns, Christian Mortalism , chap. 2.
} 
a meeting arranged by Sir Henry Vane the younger (1613-62), who was a member of the Seekers. ${ }^{5}$ During the meeting Vane interpreted Daniel 12: 2 as a metaphor of the fortunes of religious doctrines. Boyle felt an impulse to speak 'for the honor of Gods Truth': to him the biblical passage was 'the clearest one in all the Old Testament for the proof of the Resurrection', and he declared that 'we ought not to suffer the meaning of it to evaporate into Allegory' ${ }^{6}$

During his continental tour Boyle studied Aristotelian natural philosophy and visited the University of Padua, 'a famous University, but more peculiarly devoted to Esculapius then Minerva's Arts', as he put it in his Account of Philaretus. ${ }^{7}$ Indeed, Padua University was then a centre of excellence for medical learning, but in the previous century had been at the forefront of Renaissance Aristotelianism along with Bologna and Ferrara, two cities Boyle had visited during his travels in Italy. When Boyle became acquainted with Aristotle's works and saw how his authority was revered by contemporary academics, he gradually came to regard Aristotelian scholasticism with distaste, as he confessed in a short autobiographical account. ${ }^{8}$ In 'Of the Study of the Booke of Nature' Boyle for the first time expressed his distaste for Aristotelian natural philosophy and in his later 'Holy Scriptures' he dwelt upon the threats to religion posed by Aristotelianism. As Michael Hunter has pointed out, this work was most probably written around 1652-54 and it represents the key text to understand Boyle's early intellectual and religious concerns. ' 'Holy Scriptures' also contains Boyle's first explicit reference to contemporary scepticism about the resurrection of the body and the

\footnotetext{
${ }^{5}$ See M. Hunter, Robert Boyle by Himself and his Friends, with a Fragment of William Wotton's Lost Life of Boyle (London: Pickering \& Chatto, 1994), 64 (hereafter RBHF). Boyle likely heard Vane's sermon between the late 1640s and the early 1650s, since he told Pett that when the meeting took place Vane was at the peak of his political career. 'He and his party were called seekers', as Burnet reported: G. Burnet, History of my own time, ed. by M. J. Routh (6 vols., Oxford: Clarendon Press, 1823), vol. 1, 279. For Vane's intellectual biography see D. Parnham, Sir Henry Vane, theologian: a study in seventeenthcentury religious and political thought (Cranbury: Associated University Presses, 1996).

${ }^{6} R B H F, 64$. For a discussion of Boyle's stance on sectarianism and of the Jacob's thesis of a 'dialogue with sects', see M. Hunter, 'How Boyle Became a Scientist', History of Science, 33 (1995), 59-103 (8792).

${ }^{7}$ RBHF, 19.

${ }^{8}$ Cf. M. Boas Hall, Robert Boyle on Natural Philosophy. An Essay with Selections of His Writings (Bloomington: Indiana University Press, 1965), 177-79. It has been discussed by M. Hunter in his 'How Boyle Became a Scientist', 63. See also his paper 'Robert Boyle's Early Intellectual Evolution: A Reappraisal' in this issue.

${ }^{9}$ On 'Booke of Nature' and 'Holy Scriptures' see M. Hunter, 'How Boyle Became a Scientist', 67-68, 7177 nn51, 108. See also J. W. Wojcik, Boyle and the Limits of Reason (Cambridge: Cambridge University Press, 1997), 55-58.
} 
immortality of the soul. Besides Aristotle, whose conception of soul was so ambiguous that reading his works 'men should this day doubt whether or noe he thought it Immortal', Boyle tells us that in the books by authors 'either unchristned or baptized' he found that 'the Resurrection of the Dead seemes to many an Absolute Impossibility' and 'the Life of the Soule separate from the Body betwixt the Dayes of the Death \& Judgment seemes to divers modern Socinians \& others soe little to be conceiv'd that 'tis not at all to be beleev'd'. ${ }^{10}$ Those thinkers often turned to the doctrines of Aristotle, Galen, Seneca, Epicurus and Lucretius just as the Aristotelian philosopher Pietro Pomponazzi had done. ${ }^{11}$ Boyle called them 'Soule-Sleepers' who 'censure the Sensibility of the Separate Soul, as a great Absurdity to Reason, ${ }^{12}$. Notwithstanding the fact that Boyle had cited Epicurus in 'Holy Scriptures', when he wrote that work he did not regard Epicurean materialism as a threat for religion. ${ }^{13}$ As far as the immortality of the soul was concerned, Boyle understood the latter as a set of assertions on the state of the soul after death. He apparently referred to the 'soul sleepers' who believed in the resurrection of the body, but argued either (1) that the soul is an immortal substance that sleeps when separated from the body (the psychopannychist thesis) or (2) that the soul perishes with the body because it is a material substance and cannot exist without the body. However, God will reunite them and bring both to eternal life on the Last Day (this was the thnetopsychist view). As for the resurrection of the body, Boyle set out to attack the so called annihilationists, who were also called 'Libertines': they denied both the immortality of the soul and the resurrection of the body. ${ }^{14}$

\footnotetext{
${ }^{10}$ R. Boyle, The Works of Robert Boyle, edited by M. Hunter and E. B. Davis, 14 vols (London: Pickering \& Chatto, 1999-2000), vol. 13, 186-87, 191. Boyle refers to the three books of Aristotle's De anima.

${ }^{11}$ Ibid., 187. Pietro Pomponazzi (1462-1525) wrote the Tractatus de immortalitate animae (1516) and was prosecuted by the Inquisition for having stated that the immortality of the soul was beyond rational demonstration. Boyle might have heard about Pomponazzi's doctrines and his Tractatus de immortalitate animae (1516) when he was in Padua, Ferrara or Bologna, where Pomponazzi taught from 1488 to his death. See E. Gilson, 'Autour de Pomponazzi. Problématique de l'immortalité de l'âme en Italie au début du $\mathrm{XVI}^{\mathrm{e}}$ siècle', Archive d'histoire doctrinale et littéraire du Moyen Age, 18 (1961), 163-279. Later Boyle cited also Giulio Cesare Vanini (1585-1619), the Italian heterodox thinker who travelled across Europe and lived in England between 1612 and 1614: Reason and Religion. Boyle Works, vol. 8, 237. On Vanini and his influence see F. P. Raimondi, Giulio Cesare Vanini nell'Europa del Seicento (Roma-Pisa: Istituti Editoriali e Poligrafici Internazionali, 2005).

${ }^{12}$ Boyle Works, vol. 13, 211.

${ }^{13}$ For an overview on Boyle's adversaries in 'Holy Scriptures' see M. Hunter, 'How Boyle Became a Scientist', 74-78.

${ }^{14}$ In particular, annihilationism was the doctrine held by a group of enthusiasts that N. T. Burns has called 'experimental Christians', whose historical and doctrinal development dated back to Familism. As Burns put it, 'Both groups of soul sleepers [i. e. psychopannichists and thnetopsychists] believed in the personal immortality of the individual after the resurrection of the body, and so they should not be confused with the annihilationists'. N. T. Burns, Christian Mortalism , 13-21, 18.
} 
Boyle was sparing with names: he did not name his adversaries but it is apparent they made use of Aristotelian arguments. Indeed, he referred to them as his 'Peripateticke Antagonists', who denied 'the Resurrection of the Body \& the Life of the Seperate Soul' because 'they cannot conceive the Manner how the Latter should Act \& the Former be Effected'. ${ }^{15}$ Notwithstanding the fact that Boyle touched on heathen mortalism, in relation to the immortality of the soul he mainly addressed adversaries who acknowledged the authority of the Scriptures: his real target was Christian mortalism. Socinians apart, in the 1640s Richard Overton (fl. 1640-63) was the sole representative of Christian mortalism who sought to affirm the impossibility of soul's separate existence by philosophical arguments. He appealed to syllogism and the reductio ad absurdum to show that if we grant the Scriptures are to be understood in their literal sense, as he did, the idea of a separate and incorporeal soul led to absurdity. He also resorted to Aristotelian natural philosophy: accepting Aristotle's tripartite soul, one was forced to acknowledge the soul is mortal. In this case, his views fit well into Boyle's picture of his 'Peripateticke Antagonists'. ${ }^{16}$ As far as the Socinian threat is concerned, Hunter has convincingly shown that Boyle was particularly worried about Socinianism and its attempt to subordinate the letter of Scripture to reason. ${ }^{17} \mathrm{~J}$. W. Wojcik had also argued that in 'Holy Scripture' Boyle began to emphasize the limits of reason in response to Socinians, who claimed that reason was the touchstone for biblical interpretation. ${ }^{18}$ Boyle's insistence on the threats posed by Socinianism should also be read in the light of Socinian mortalism. Indeed, some Socinians were soul sleepers, like Joachim Stegmann who in his Brevis Disquisitio (1635) argued that psychopannichism was a doctrine confirmed by a literal interpretation of the Scripture. ${ }^{19}$

\footnotetext{
${ }^{15}$ Boyle Works, vol. 13, 201.

16 R. Overton, Mans Mortallitie, or a Treatise Wherein 'tis proved, both Theologically and Philosophically, that the whole Man (as a rationall Creature) is a Compound wholly mortall... (Amsterdam [i.e. London]: John Canne, 1643), 11-14 et passim (On the title-page of the copy in the British Library 'Amsterdam' is deleted and replaced with 'London'). In 1655 an enlarged and revised edition of Overton's pamphlet was issued under the title Man Wholly Mortal and was reprinted in 1674 and 1675. An account of Overton's ideas and their impact is to be found in N. T. Burns, Christian Mortalism, 154-57 and DNB.

${ }^{17}$ M. Hunter, 'How Boyle Became a Scientist', 75, 86.

${ }^{18}$ J. W. Wojcik, Boyle and the Limits of Reason 55-59.

${ }^{19}$ The Brevis Disquisitio was translated in English by John Biddle (c. 1615-62) in 1652. Cf. the preface to the English edition, arguably written by Biddle, 'To The Christian Reader', in J. Stegmann, Brevis Disquisitio: Or, A Brief Enquiry Touching a Better Way Then Is commonly made use of, to refute Papists, and reduce Protestants to certainty and Unity in Religion (London: Richard Moone, 1652), sig. A3v. On
} 
Boyle seemed to think, however, that rational arguments were not effective to confute this kind of 'Aristotelian infidelity': 'Reason should miscarry when soaring above her own spheare', he said. ${ }^{20}$ In other words, reason cannot offer a direct proof of the truth of revelation. However, he was aware that resurrection and immortality were different issues. Indeed, proving the immortality of the soul was not a task as difficult as bodily resurrection. ${ }^{21}$ Overall 'Holy Scriptures' proves that Boyle was sceptical about rational proofs of immortality. For instance, Boyle mentioned Descartes' Traité des passions de l'âme (1649) as an example of how the immortality of the soul was "naturally more demonstrable by Reason, then any Physicall Assertion of any sect of Philosophers', but he tellingly commented 'How Truly, it were forraine to my Argument to detemine'. ${ }^{22}$ As we shall see, Boyle came back on this topic in Excellency of Theology (1674), when he discussed the immortality of the soul and Descartes' cogito argument. However, it is worth noting that in 'Holy Scriptures' Boyle did not flatly deny that reason could have a part in the discussion of the articles of revelation. Having criticized the excessive rationalism of Socinians and the appeal to Aristotle's authority, Boyle felt he had to offer an alternative. One possibility would have been to utterly reject the very role of reason in our knowledge both of the Scriptures and nature. Indeed, among the authors he had read, Johann Baptista van Helmont seemed to maintain such a doctrine. As recent studies have shown, van Helmont was Boyle's favourite chemical philosopher: 'Holy Scriptures' itself includes references to Helmontian theories and principles. ${ }^{23}$ Boyle also cited van Helmont's theory of knowledge as a statement about the limits of reason, but he chose to pursue another strategy for defending the truth of Christian

Biddle, Paul Best and English Socinianism during the Interregnum, cf. S. Mortimer, Reason and religion in the English revolution: the challenge of Socinianism, (Cambridge: Cambridge University Press, 2010), pp. 158-67. On Socinian mortalism see N. T. Burns, Christian Mortalism, 142 and J. McLachlan, Socinianism in Seventeenth Century England (Oxford: Oxford University Press, 1952), 92.

${ }^{20}$ Boyle Works, vol. 13, 202.

${ }^{21}$ Ibid., 209.

${ }^{22}$ Ibid., 190. Boyle might refer to Traité des passions, I, art. IV, where Descartes differentiated soul's function, i. e. thought, from bodily ones: Euvres de Descartes, ed. par C. Adam et P. Tanney (13 vols., Paris: Cerf, 1897-1913), vol. XI, 329 (hereafter AT).

${ }^{23}$ Ibid., 204-5. On the Helmontian content of 'Holy Scriptures' see W. R. Newman and L. M. Principe, Alchemy Tried in the Fire: Starkey, Boyle and the Fate of Helmontian Chymistry (Chicago: University of Chicago Press, 2002), 223-24. For Boyle's reception of Helmontian chemistry, see A. Clericuzio, 'From van Helmont to Boyle. A study of the transmission of Helmontian chemical and medical theories in seventeenth-century England', British Journal for the History of Science, 26 (1993), 303-34. 
religion. ${ }^{24}$ Although Boyle favourably commented on van Helmont's stance on the limits of reason, he did not seem receptive to Helmontian mysticism, but seemed to believe that the proper strategy for defending the credibility of the Christian religion cannot lay aside reason.

With regard to the resurrection, the virtuoso should appeal to miracles literally interpreted, since those supernatural phenomena were the surest testimonies of the divine origin of the Scriptures. Indeed, to Boyle miracles were crucial 'in making our Choyce of Religion which is the importantst action of our Understanding', as he stated in his later papers on miracles. ${ }^{25}$ Among the miracles delivered in the Bible, the resurrection of Christ was the ultimate proof of the 'Divine Authority' of Christianity. The resurrection was then the primary miracle: 'A Miracle as much transcending other Miracles, as other Miracles exceed the Common Course of Nature', as Boyle put it. ${ }^{26}$ When Boyle set out to define the role of reason in theological matters, he did it by referring to the resurrection of the body. 'In the Present Case of the Resurrection, the Dogme it Selfe being acknowledg'd Cleare in the Scriptures', Boyle argued,

the Taske of Reason, is, not to give Proofes that there Must, or make out the Modus how there can, be one; but to show that there can noe inevitable Demonstration be given that there cannot be one. [...] Reason then needs do the Article of the Resurrection noe other service, than defensively to mayntaine, That it imports nothing that's Impossible to Omnipotence. ${ }^{27}$

As far as scriptural mysteries are concerned, reason is not able to make out the 'modus'. but when we acknowledge miracles as historical facts, as testimonies to the being of a powerful God, then supernatural phenomena such as resurrection might be partly

\footnotetext{
${ }^{24}$ In 'Holy Scriptures' Boyle summed up van Helmont's theory of knowledge: Boyle Works, vol. 13, 187. He apparently referred to the Ortus Medicinae, in particular to the sections 'Studia Authoris' and 'Venatio Scientiarum', in J.B. van Helmont, Ortus medicinae (Bruxelles: Culture et civilisation, 1966), 17, 26. On van Helmont's theory of knowledge see. W. Pagel, Joan Baptista van Helmont. Reformer of science and medicine (Cambridge: Cambridge University Press, 1982), chap. 3.

${ }^{25}$ BP 7, fol. 106, in J. J. MacIntosh, Boyle on Atheism (Toronto: University of Toronto Press, 2005), 274.

${ }^{26}$ Boyle Works, vol. 13, 189.

${ }^{27}$ Ibid., 202.
} 
discussed on natural grounds. In this strategy experiments had to play a role: they could help reason to prove that the miracle of resurrection did not involve contradictions, that is, it is above reason but not contrary to reason.

The objections against the resurrection Boyle was concerned about were not new at all. Indeed, they dated back to early Christianity and were raised by heathen critics such as Celsus and Porphyry. In particular, the early critics of the possibility of resurrection questioned two key points of the Christian doctrine of the resurrection: (1) the material continuity between the deceased body and the risen; (2) the identity between the two. Could the scattered parts of a dead body be reassembled? This being the case, would the resurrected body be the same as the dead one $?^{28}$ The Fathers of the Church had replied to arguments drawn from dissolution of substances in digestion and cannibalism, sometimes appealing to the power of God and even to contemporary medicine, as Athenagoras of Athens did. Boyle strove to answer these questions by providing evidence for the issue of material continuity, the major philosophical objection to the problem of resurrection since Christian antiquity. One of the crucial scriptural passages the doctrine of resurrection rested on is contained in the Apostle Paul's first letter to the Corinthians (1 Cor., 15: 35-38). ${ }^{29}$ Paul had recourse to the seed metaphor to explain the possibility of resurrection and, as will be seen, in 'Possibility of Resurrection' Boyle dwelt upon it. The seed metaphor appeared to be a satisfactory solution to the problem of numerical identity, but it does not imply necessarily material continuity: the seed grows but new matter is added to it. ${ }^{30}$

Responses to that sort of criticism were to be found in Hugo Grotius' (1583-1645) De Veritate Religionis Christianae (1627), a work Boyle knew very well. In Book II of De

\footnotetext{
${ }^{28}$ On the early debate on resurrection cf. R. M. Grant, 'The Resurrection of the Body', Journal of Religion, 28, no. 2 and no. 4 (1948), 120-30, 188-208 (193-97).

29 'But some man will say, How are the dead raised up? and with what body do they come? Thou fool, that which thou sowest is not quickened, except it die: And that which thou sowest, thou sowest not that body that shall be, but bare grain, it may chance of wheat, or of some other grain: But God giveth it a body as it hath pleased him, and to every seed his own body': quoted from KJV, the same quotation in Boyle, Boyle Works, vol. 8, 302.

${ }^{30}$ For instance, it was espoused by Origen. On this crucial issue and seed images of resurrection cf. C. Walker Bynum, The Resurrection of the Body in Western Christianity, 200-1336 (New York: Columbia University Press, 1995), 3-17 (6-10).
} 
Veritate the Dutch apologist answered the argument based on the dissolution of dead bodies arguing that an omnipotent God can recollect and unite the scattered parts of decomposed bodies like 'Chymicks in their furnaces and vessels, gather into one, and reunite things of the same nature'. ${ }^{31}$ In 'Holy Scriptures' Boyle resorted to chemistry too, as he did later in 'Possibility of Resurrection'. In particular he had recourse to a well-known experiment, the so-called palingenesis of plants. ${ }^{32}$ A decade earlier, in his Religio Medici (1642) Sir Thomas Browne had considered the possibility of resurrection and he also had recourse to palingenesis. According to him, this experiment provided a notable instance of resurrection. ${ }^{33}$ When he was writing 'Booke of Nature', it is more than likely that Boyle had read Browne's book. ${ }^{34}$ Apart from palingenesis, Boyle also referred to the 'Revivication of mercury' echoing Sir Thomas Browne's words on 'the artificial resurrection and vivification of mercury, ${ }^{35}$

\section{Boyle and 'the Genius of this Age'}

At some point in his life, arguably during the 1660s, Boyle realized that the Christian religion had to be defended 'in a way suited to the Genius of this Age, 36 , as he put it. An interesting document entitled 'Introduction to my loose Notes Theological' and the preface to Reason and Religion provide us with evidence of this shift in Boyle's intellectual evolution. The former was written around 1684, when Boyle had read Pascal's Pensées (1670) and was inspired to publish his reflections in an aphoristic

\footnotetext{
${ }^{31}$ Quoted from the first English translation of De Veritate, H. Grotius, True religion explained and defended against ye archenemies thereof in these times In six bookes. Published by authority for the co[m]mon good. (London: John Haviland, 1632), 105-6 (the English edition erroneously reports the section as XII instead of X). For the Latin edition see Opera omnia theologica (3 vols., Londini: Mosem Pitt, 1679), vol. 3, 38.

32 On palingenesis in 'Holy Scriptures' and in previous alchemical literature, W. R. Newman, Promethean Ambitions. Alchemy and the Quest to Perfect Nature (Chicago: University of Chicago Press, 2004), 227-32. See also F. Secret, 'Palingenesis, Alchemy, and Metempsychosis in Renaissance Medicine', Ambix, 26 (1979), 81-92.

${ }^{33}$ T. Browne, Religio Medici (London: A. Crooke, 1642), 91.

${ }^{34}$ H. Fisch, 'The Scientist as Priest: a Note on Robert Boyle's Natural Theology', Isis, 44 (1953), 252-65 (253-55); M. Hunter, 'How Boyle Became a Scientist', 84.

${ }^{35}$ Compare Boyle Works, vol. 13, 204 and T. Browne, Religio Medici, 90-91. The 'revivification' (shortened 'revivication') denoted a chemical process consisting in the restoration of a substance (usually metals) to a pure state from a mixture. It is not a coincidence that from the early modern period the term meant also resurrection. Cf. OED.

${ }^{36}$ Boyle Works, vol. 14, 279.
} 
form. ${ }^{37}$ Boyle reported that 'many years ago' he had decided to devote himself 'to prove the truth \& declare the Excellency of Christian Religion'. He confessed that he had partly followed Grotius, Philippe de Mornay (1549-1623) and the Spanish humanist Juan Luis Vives (1493-1540), authors he cited in 'Holy Scriptures'. ${ }^{38}$ However, Boyle also declared that in his mature theological writings he considered 'such controversies as have not been either at all, or at least fully handled by the Excellent Vives, Mornaeus \& Grotius' ${ }^{39}$ Arguably, the works of those apologists could not reach an audience in such an age, when 'the Authority is much less reverenc'd then formerly it was' and a theological or philosophical doctrine was judged on 'its being agreeable to the Principles of Modern Philosophy'. ${ }^{40}$ Therefore, Boyle realized that he had to change his strategy for defending the credibility of Christianity. He needed to shift from the defence of the language of the Scriptures - as he did in Style of the Holy Scriptures (1661), which originated as part of 'Holy Scriptures'41 - to a new kind of apologetics, which employed the same weapons deployed by his new adversaries. It is interesting to quote the passage in full:

I was careful that most of my Discourses should not be mainly directed against the Critical or Philological Adversaries, if I may so call them, of Christianity that quarrel only with the History, the Style of the Scripture, or some Lawes deliver'd in it; but so fram'd as to assert \& vindicate the fundamental points of Religion against Philosophical Unbeleivers, that oppose them as they propound Mysteries accus'd of being Unintelligible, or teach some other Doctrine that are [sic] pretended to be repugnant to the dictates of right Reason, or what in the Objectors sense[,] is equivalent, the New Philosophy. Of these tracts of mine hitherto spoken of, some have already upon certain Occasions been permitted to come abroad, thô none of them with the Authors name prefix't to it, except a short Discourse of the Possibility of the Resurrection. ${ }^{42}$

\footnotetext{
${ }^{37}$ For references about dating see the introductory note in Boyle Works, 14, xxx. Boyle did not publish them and some related texts survive in the Boyle Papers. Part of them are transcribed in J. J. MacIntosh, Boyle on Atheism, 231-32.

${ }^{38}$ As Hunter has pointed out, Boyle cited these authors in 'Booke of Nature' and in 'Holy Scriptures', but they disappeared in his later writings : M. Hunter, 'How Boyle Became a Scientist', 78.

39 Boyle Works, vol. 14, 279.

${ }^{40}$ Ibid., 280.

${ }^{41}$ Cf. J. W. Wojcik, Boyle and the Limits of Reason , 95-97.

${ }^{42}$ Boyle Works, vol. 14, 280.
} 
Boyle here referred to the theological treatises he published in the 1670s: Excellency of Theology (1674) and Reason and Religion (1675). Indeed, on the title page of the first edition of Excellency of Theology Boyle appeared as 'T.H.R.B.E.' and Reason and Religion was attributed to 'T.E., a Layman'. As we know, 'Possibility of Resurrection' was annexed to Reason and Religion, but it was published under his name. Moreover, both Excellency of Theology and Reason and Religion appear to have been compiled during the 1660s. ${ }^{43}$ Finally, the preface to Reason and Religion partly overlaps with this 'Introduction': Boyle explained that the new challenge from 'our new Libertines' who 'deny those very Principles of Natural Theology' required different weapons from those he had deployed in 'Holy Scriptures'. 44

Between the composition of 'Holy Scriptures' and the mid-1660s, criticism of Socinianism gradually disappeared from Boyle's published and unpublished writings. This shift in Boyle's intellectual evolution may have been partly influenced by the virtuoso John Beale. It is likely Boyle had sought Beale's advice on Socinian theology, as is apparent from Beale's letter to Boyle of 11 October 1665, which contains a brief discussion on Socinus's Praelectiones Theologicae (1609). ${ }^{45}$ Two years earlier, Beale had urged Boyle to give up open criticism of Socinianism. He had also recommended him to focus upon what he styled 'experimental theology', that is, to deploy the 'experimental natural philosophy' described in Usefulness of Natural Philosophy I (1663) in defence of Christian religion. Indeed, Beale commented on a passage contained in Usefulness of Natural Philosophy dealing with the interpretation of Rom.1: 20. Boyle opposed Socinus's interpretation, but Beale declared that 'you do not (since you need not) engage yourself expressly against the interpretation of Socinus'. Beale suggested prudence because Socinus had been a formidable thinker; neither Grotius nor others had defeated him but 'have so often rendered up their cudgels to him'. ${ }^{46}$

\footnotetext{
${ }^{43}$ Cf. introductory notes. Boyle Works, vol. 8, xi-xiv, xxi-xxvi.

${ }^{44}$ Boyle Works, vol. 8, 236-37. On libertinism and atheism see M. Hunter, Science and Society in Restoration England (Cambridge: Cambridge University Press, 1981), chap. 7; Id., 'Science and Heterodoxy: An Early Modern Problem Reconsidered', in Id., Science and the Shape of Orthodoxy. Intellectual Change in Late Seventeenth-Century Britain (Woodbridge: The Boydell Press, 1995), 225-44.

${ }^{45}$ Beale to Boyle, 11 October 1665. Correspondence, vol. 2, 554.

${ }^{46}$ Correspondence, vol. 2, 147-48. Beale referred to p. 62 of the first edition of Usefulness: R. Boyle, Some Considerations touching the Usefulnesse of Experimentall Natural Philosophy, Propos'd in Familiar Discourses to a Friend, by way of Invitation to the Study of it (Oxford: Richard Davis, 1663),
} 
Nonetheless, Boyle's shift away from Socinianism to 'experimental theology' should also be read in the light of the new intellectual and theological context in the mid-1660s, which was different from that of the early 1650s. Feelings of hostility towards the Royal Society dominated the scene, with attacks by some divines, like the Oxford Public Orator Robert South and the Lady Margaret professor of divinity Peter Gunning at Cambridge. The well known publication of Thomas Sprat's History of the Royal Society (1667) sparked off a heated debate: the Royal Society was perceived as a threat to the religious and academic establishment. Cartesianism and the new philosophy in general were also under attack. ${ }^{47}$

Boyle himself was aware of the dangers of an enthusiastic adherence to mechanical principles. He associated this view with a general distaste for theology that he saw among learned men who espoused mechanical philosophy. It is worth noting that Excellency of Theology was addressed to a Cartesian, 'Physeophilus', who believed in the authority of the Scriptures, opposed Aristotelian scholasticism and, nevertheless, thought of theology as an unworthy subject for natural philosophers. ${ }^{48}$ On the other hand, in the preface to Reason and Religion Boyle had hinted at 'our new Libertines'. They employed 'Epicurean, or other Mechanical, Principles of Philosophy' to deny the existence of 'a Future State (after this life is ended)'. ${ }^{49}$ One of the libertines Boyle was thinking of was most likely Thomas Hobbes, who indeed in his Leviathan (1651) had denied the existence of immaterial substances as well as the immortality of the soul. It is worth noting that Boyle had been anxious about the theological implications of Hobbes' natural philosophy since 1662. In the preface to his Examen of Hobbes' Dialogus

62 , i. e. Boyle Works, vol. 3, 241. For a comment on the letter see also J. W. Wojcik, Boyle and the Limits of Reason , 22-3. Beale and Boyle began to correspond in 1663, although they communicated indirectly via Hartlib from the late 1650s: see M. Stubbs, 'John Beale, Philosophical Gardener of Herefordshire Part I. Prelude to the Royal Sociey (1608-1633), Annals of Science, 39 (1982), 467-74.

47 On this issue see M. Hunter, Science and Society in Restoration England, esp. chap. 6; Id., 'Latitudinarianism and the 'Ideology' of the Royal Society: Thomas Sprat's History of the Royal Society (1667) Reconsidered', in Id., Establishing the New Science: The Experience of the Early Royal Society (Woodbridge: The Boydell Press, 1989), 45-71. On the attacks from the Cambridge milieu see J. Gascoigne, Cambridge in the age of Enlightenment. Science, religion and politics from the Restoration to the French Revolution (Cambridge: Cambridge University Press, 1989), 55-57.

${ }^{48}$ Boyle Works, vol. 8, 9.

${ }^{49}$ Ibid., 237. 
Physicus (1661) Boyle touched on the 'dangerous opinions about some important, if not fundamental articles of religion, I had met in his Leviathan', and he seemed to look on Hobbes' theological opinions as an integral part of his 'demonstrative way of philosophy' ${ }^{50}$ In particular, Boyle was concerned about Hobbes' views on the origin of motion and his conception of God as a corporeal entity. Boyle went back over that topic in Reason and Religion and strove to show that Hobbes' statement that motion had its origin from another 'body contiguous and moved' was inconsistent with his belief in a corporeal deity: if we grant that God originated motion, Boyle argued, Hobbes' position involved a regressus ad infinitum. ${ }^{51}$

In 1674 Boyle also revisited Hobbes' theories on materialism and mortalism: the preface to his Animadversions upon Mr Hobbes's Problemata de Vacuo contains an explicit reference to the content of the third chapter of the Appendix to Leviathan. Hobbes' Appendix was added to the Latin edition of the Leviathan in Hobbes's Opera Philosophica published in 1668. ${ }^{52}$ In the Appendix Boyle found a restatement of the doctrine of the corporeal deity. Echoing what he delivered in the English edition about the absurdity of the notion of incorporeal substance, in the third chapter of the Appendix Hobbes claimed that there was no scriptural evidence supporting the notion of

\footnotetext{
${ }^{50}$ Boyle Works, vol. 3, 112.

${ }^{51}$ Ibid., 121-22, 134; vol. 8, 259-61. Boyle discussed and criticized Hobbes's statement in De Corpore 'There can be no cause of motion, except in a body contiguous and moved': De Corpore, II. IX, sect. 7, in Thomae Hobbes Malmesburiensis opera philosophica quae Latine scripsit omnia..., ed. Sir W. Molesworth (5 vols., London: John Bohn, 1839-45), vol. 1, 110-11 (hereafter OL); The English Works of Thomas Hobbes of Malmesbury, ed. Sir. W. Molesworth (11 vols., London: John Bohn, 1839-45), vol. 1, 124 (hereafter EW). For a discussion of Boyle's argument see A. Clericuzio, 'God and the Physical World in Boyle's Thought', 1037. Cf. also S. Shapin and S. Schaffer, Leviathan and the Air-Pump (Princeton: Princeton University Press, 1985), 204-5.

${ }^{52}$ Boyle Works, vol. 8, 162. Indeed, in the preface Boyle claimed that he wrote his Animadversions just after the publication of Hobbes' Problemata Physica (1662) but they were 'causally mislaid e're they were finished'. He declare that 'I had still persisted in my silence, if Mr. Hobbes had not as 'twere summon'd me to break it by publishing again his Explications'(Ibid., 161). Indeed, in 1668 the Problemata were reprinted in the Opera Philosophica along with the Appendix: cf. T. Hobbes, Thomae Hobbes Malmesburiensis Opera philosophica ... (Amstelodami: Ioannem Blaeu, 1668).
} 
immaterial substance and that 'God is body'. ${ }^{53}$ Hobbes also repeated his early ideas on the nature and fate of the soul: the Scriptures did not teach the immortality of the soul. ${ }^{54}$

Although Boyle could not accept Hobbes' own version of mechanism, he was aware that the mechanical philosophy itself was under attack and should be defended. He felt he had to convince divines like Richard Baxter and philosophers like Henry More that the mechanical philosophy, at least in his own corpuscular interpretation, was not contrary to Christianity and to the immortality of the soul. In 1667 Oldenburg informed Boyle that Beale had told him that the non-conformist divine Baxter in his The Reasons of the Christian Religion (1667) 'inveighes [...] against the Corpuscularian (called by him the Somatical) Philosophy, and traduces it as if it supplanted our future Estate'. ${ }^{55}$ A few years later in his Enchiridion Metaphysicum (1671) More launched an attack on Descartes and Cartesianism. To him Cartesian philosophy was simply disguised atheism, as More repeated in his letter to Boyle of December $1671 .^{56}$ When Boyle responded to More's interpretation of his pneumatic and hydrostatical experiments, at the beginning of the 'Hydrostatical Discourse' (1672), he conceded Descartes had overlooked the wider implications of his own system of philosophy. He could have put more emphasis on God's power and providence, but Boyle flatly refused to consider him an atheist. ${ }^{57}$

Immortality can be proved, although not directly, by rational arguments, as Descartes had shown in his Traité des passions. If we believe Boyle's own words, this was the

\footnotetext{
${ }^{53}$ For the text of the 1668 Appendix see G. Wright, Religion, Politics and Thomas Hobbes (Dordrecht: Springer, 2006), 35-173, III, §§176-80, 148-50, hereafter Appendix. See also T. Hobbes, Leviathan: with selected variants from the Latin edition of 1668, ed. by E. Curley (Cambridge-Indianapolis: Hackett Publishing Company, 1994), I.IV, §21; I. XII, §§6-8, 21, 64-66 (hereafter Leviathan).

${ }^{54}$ See Appendix, I, §§41-56, 60-73. For Hobbes' mortalism see Leviathan, IV.XLIV, esp. §§14-16, 41820 and N. T. Burns, Christian Mortalism, chap. 4. On the theological content and background of Leviathan, A. P. Martinich, The Two Gods of Leviathan. Thomas Hobbes on Religion and Politics (Cambridge: Cambridge University Press, 1992). On contemporary reactions to Hobbes' materialism, S. I. Mintz, The Hunting of Leviathan (Cambridge: Cambridge University Press, 1962), chaps. IV-V.

55 Oldenburg to Boyle, 24 December 1667. Correspondence, vol. 3, 386. Cf. R. Baxter, The Reasons of the Christian Religion (London: R. White, 1667), esp. the appendix 'Defending the Soul's Immortality against the Somatists or Epicureans, and other Pseudophilosophers'.

${ }^{56}$ H. More, Enchiridion Metaphysicum (Londini: E. Flesher, 1671), sig. A1v-B2v, A3+1; More to Boyle, 4 December 1671. Correspondence, vol. 4, 231-32.

${ }^{57}$ Boyle Works, vol. 7, 141-42.
} 
sole work by Descartes he had read until the late 1650s. ${ }^{58}$ On the contrary, Excellency of Theology and Reason and Religion show that Boyle knew Descartes's Principia Philosophiae (1644), his Meditationes de prima philosophia (1641) and the Objectiones and Responsiones very well. ${ }^{59}$ Furthermore, in the mid-1660s Boyle discussed Cartesian philosophy with Oldenburg. During the summer of 1665 Oldenburg reported on 'two Disputations, Anti-Cartesian ones, held at Paris by the Jesuits in their College of Clermont' to Boyle. ${ }^{60}$ Boyle responded quickly asking Oldenburg for further details on the Jesuits' criticism of Descartes's physics, and referred to his lost The 'Scepticall Naturalist', a work which dealt with 'what I have had occasion to object against Descartes'. 61

I believe Boyle's views on immortality developed when he began to reflect on what Descartes had taught on the issue. Although revelation is the surest testimony of immortality, he claimed that philosophy could provide arguments to defend immortality from materialism. However, Boyle felt the need to define the limits of a philosophical treatment of the issue, as appears from the content of the first section of Excellency of Theology. Despite his distaste for metaphysics and his aversion for system-building, Boyle was genuinely interested in Descartes' brand of dualism. In Excellency of Theology he declared that Descartes' arguments of the Second and Fourth Meditations were effective against materialistic accounts of the soul, but ineffective when the opponents of immortality acknowledged the being and power of God. According to Boyle, the problem lies at the core of Descartes' definition of the soul. Boyle discussed the objection that 'Physeophilus' could have raised against the need of theology to know such truths concerning soul: 'the Immortality of the Soul may be sufficiently prov'd by the sole Light of Nature, and particularly has been demonstrated

\footnotetext{
${ }^{58}$ Cf. 'Essay on Spontaneous Generation'. Boyle Works, vol. 13, 279. The essay was composed between c. 1659 and c. 1665 : ibid., xlvii-xlviii.

59 John Aubrey claimed that Hooke 'made him [Boyle] understand Des Cartes' Philosophy' is in J. Aubrey, Brief Lives, edited by A. Clark (2 vols., Oxford: Clarendon Press, 1898), vol. 1, 411. See also M. Hunter, Boyle: Between God and Science, 106 n9.

${ }^{60}$ Oldenburg to Boyle, 4 July 1665, Correspondence, vol. 2, 488. On those disputations see See R. Ariew, 'Descartes and the Jesuits: Doubt, Novelty and the Eucharist', in Jesuit Science and the Republic of Letters edited by M. Feingold (Cambridge-Mass.: The MIT Press, 2003), 157-94, 157.

${ }^{61}$ Boyle to Oldenburg, 8 July 1665. Correspondence, vol. 2, 494. On Boyle's reading of Cartesian philosophy and Occasionalism see P. Anstey, 'Boyle on Occasionalism: An Unexamined Source' , Journal of the History of Ideas, 60 (1999), 57-81 (65-69).
} 
by your great Des Cartes' ${ }^{62}$ Boyle pointed out that Descartes' followers had failed to understand the actual scope of his treatment of the soul. Descartes himself had indeed acknowledged that immortality did not follow from the demonstration that soul and body are distinct substances. ${ }^{63} \mathrm{He}$ had proved that soul is an incorporeal substance but, Boyle argued, his argument did not imply that the soul is immortal: 'we are yet much beholding to Divine Revelation for assuring us, that its Duration shall be endless' ${ }^{64}$ The essential attribute of the soul, namely to be a 'thing that thinks' (res cogitans), could not assure us that the soul will outlive the body in a separate state: the attribute of thinking by no means led to immortality. From Descartes's argument we can only conclude that if the soul survives the body, it will continue to think. It was not Descartes' fault, but the fault of his followers who had overestimated the power of reason:

Nor do I wonder he [Descartes] should be of that mind. For all that meer Reason can demonstrate, may be reduced to these two things; One, that the Rational Soul, being an Incorporeal Substance, there is no necessity that it should perish with the Body; so that, if God have not otherwise appointed, the Soul may survive the Body, and last forever: The other, that the Nature of the Soul, according to Des Cartes, consisting in its being a Substance that thinks, we may conclude, that, though it be by death separate from the Body, it will nevertheless retain the power of thinking. But now, whether either of these two things, or both, be sufficient to endear the state of separation after death, to a considering man, I think may be justly question' ${ }^{65}$

In conclusion, Boyle acknowledged that natural reason could grasp at the immortality of the soul, although its ultimate fate is a matter of 'Divine Revelation'. It is worth noting that in the 1660s Boyle also began to regard the Cartesian beast-machine doctrine as a

\footnotetext{
${ }^{62}$ Boyle Works, vol. 8, 23.

${ }^{63}$ He cited Descartes's Replies to the Second Objections and his answer to Elizabeth, Princess of Bohemia, who had asked him his opinion on the fate of the soul. See Boyle Works, vol. 8, 24-25; AT VII 127-28, 153; Elizabeth to Descartes, 28 October 1645 and Descartes to Elizabeth, 3 November 1645, AT AT IV 320-24, 330-34. Cf. also J. Cottingham, 'Cartesian dualism: theology, metaphysics, and science', in The Cambridge Companion to Descartes edited by J. Cottingham (Cambridge: Cambridge University Press, 1992), 236-57 (237-41).

${ }^{64}$ Boyle Works, vol. 8, 24. For Descartes's hyperbolic doubt and the certainty of the cogito in the Meditationes, see AT VII 34-35, 53-62. The same argument is in the Discourse de la méthode, AT VI 3132.

${ }^{65}$ Boyle Works, vol. 8, 25.
} 
powerful argument to support the immortality of the soul. ${ }^{66}$ In his brief notes on the theory of the bête machine he addressed 'Peripatetick and Divines' or 'those modern Epicureans' who ridiculed Descartes' views or condemned them as 'of very dangerous Consequence to the Grand Article of the Immortality of the Soul'. Boyle argued that they did not realize that Descartes' beast-machine doctrine and his brand of dualism represented 'the best \& most proper Physical Medium whereby that Fundamentall Doctrine [i. e. the immortality of the soul] can be solidly establisht' ${ }^{67}$

\section{Soul, Body, Resurrection and Mechanical Philosophy}

Descartes' metaphysics could help the virtuoso in defending the immortality of the soul, but it was far from being effective against the 'annihilationists'. Between 'Holy Scriptures' and 'Possibility of Resurrection' Boyle had fully developed his corpuscular hypothesis: he had written and published all his best-known works on it, from his Certain Physiological Essays (1661, 1669) to Origin of forms and qualities (1666, 1667). He had also shown how his own version of mechanism could explain particular qualities, such as colours, cold, heat and so forth. In 1675 Boyle also published his last work on qualities, tellingly entitled Mechanical Origine of Qualities (1675). 'Possibility of Resurrection' appeared the same year, probably at the beginning of the year. Indeed, a review of the treatise appeared in the 22 February 1674/75 issue of the Philosophical Transactions: the article laid great emphasis on the scientific content of 'Possibility of Resurrection' and its apologetic task. 'Possibility of Resurrection' intended to show 'that sound Philosophy may furnish us with good Weapons for the defence of our Faith'. The work also defended the corpuscular hypothesis from accusations of impiety arguing 'that Corpuscularian Principles may not only be

\footnotetext{
${ }^{66}$ On the contrary, the young Boyle seemed to acknowledge that animals have 'Passions and Pleasures', following the majority of English naturalists in opposing Descartes's theory: see M. R. Oster, 'The 'Beame of Diuinity': Animal Suffering in the Early Thought of Robert Boyle', The British Journal for the History of Science, 22 (1989), 151-79 (160).

${ }^{67}$ Cf. BP 17, fols. 166v-167r, published in Y. Conry, 'Robert Boyle et la doctrine cartésienne des animaux-machines', Revue d'Histoire des Sciences, 33 (1980), 69-74 (70-71). In this paper Boyle explicitly referred to Gassendi's remarks on the beast-machine doctrine in his Fifth Objections to the Meditations (AT VII 268-71). Gassendi had maintained that imagination is common to beasts an men, but Boyle pointed out that he 'had ascrib'd too much to the Imaginative faculty of Bruits', though later he mend his ways. On Gassendi's views on the soul, see O. R. Bloch, La Philosophie de Gassendi. Nominalisme, Matérialisme et Métaphysique (La Haye: Martinus Nijhoff, 1971), 362-68.
} 
admitted without Epicurean Errors, but be employed against them'. Overall the reviewer for the Philosophical Transactions stressed the importance of the 'Observations and Experiments' contained in Boyle's treatise: they produced empirical evidence of material continuity in the natural realm and in the development of the human body. Lastly, he emphasized that the 'corpuscularian principles' provided a better account of the resurrection than the Aristotelian concept of soul did. ${ }^{68}$

Nonetheless, in the preface to 'Possibility of Resurrection' Boyle tells us that he had written it 'divers years ago'. Indeed, part of its contents overlaps with 'Holy Scriptures', but the treatise appears to be almost entirely rewritten. Boyle decided to add 'Possibility of Resurrection' shortly before the publication of Reason and Religion. While the latter was still in press, he met the publisher, probably Oldenburg, and discussed with him the subject of his forthcoming book. Subsequently he remembered his paper on the possibility of resurrection; and took the manuscript to the publisher who persuaded him to publish it 'notwithstanding its Imperfections, and my unwillingness to let it go abroad'. ${ }^{69}$ The arguments against which Boyle responded in 'Possibility of Resurrection' were the same he dealt with in 'Holy Scriptures', though in the former he offered a more accurate account of the argument from dissolution. ${ }^{70}$

As far as his response is concerned, Boyle partly continued to resort to palingenesis. However, it could be argued that in the 1660s Boyle became increasingly aware that the empirical and theoretical features of his corpuscular hypothesis were weapons which he could deploy in his 'spiritual warfar against Atheists \& other unbeleivers'. ${ }^{71}$ He did not think that explanations in terms of particulate matter and motion could physically prove the possibility of the miracle par excellence. His 'Physico-Theological Considerations about the Possibility of Resurrection' rather suggest that he had recourse to physical

\footnotetext{
68 'An Account of Some Books', Philosophical Transactions, no. 111, 22 February 1674/75, 9 (1674), 246-47.

${ }^{69}$ Boyle Works, vol. 8, 297. Arguably, the manuscripts Boyle referred to in the preface are now located in BP 7, fols. 28-42. However, as Wojcik pointed out, none of the manuscript passages appear verbatim in the published version. J. Wojcik, Boyle and the Limits of Reason, 58n.

${ }^{70}$ Boyle Works, vol. 8, 304.

71 'Introduction to my loose Notes Theological'. Boyle Works, vol. 14, 281.
} 
phenomena - especially phenomena relating to the human body - interpreted in corpuscular terms in order to prove that the truth revealed by the resurrection of the same physical body was not a physical impossibility. As Clericuzio has recently pointed out, Boyle's main aim was to produce evidence that natural agents, when 'divinely excited', could bring about resurrection: Boyle strove to demonstrate that resurrection was not contrary to reason, but above reason. According to Clericuzio, Boyle mainly provided two examples to prove the possibility of resurrection: the palingenesis of plants and the reduction to the pristine state. In particular, in his explanation of the former, Boyle resorted to the notion of seminal principles. ${ }^{72}$ Nonetheless, it seems that in 'Possibility of Resurrection' Boyle downplayed the role of palingenesis as evidence for resurrection. Indeed, the treatise rather highlights the potential importance of the theoretical framework provided by his corpuscular hypothesis. It also shows Boyle's conception of the human body as a dynamic machine, one of his greatest accomplishments during the Oxford period. ${ }^{73}$

It remains true that Boyle's main concern was to show that the resurrection of the body was above reason. In his preliminary remarks he clearly ruled out the possibility that a mere physical agent could be able to restore a dead body. Resurrection transcends the power of any physical agent whatsoever and is beyond the 'Mechanical Powers of matter': we cannot explain it by size, shape and motion of material particles. Boyle also argued that if we set the omnipotent God aside resurrection becomes 'morally impossible'. Apart from supernatural revelation, we have neither a 'concurrence of probability' that could be provided by historical experience nor any other kind of testimony: from its title-page onwards 'Possibility of Resurrection' is indeed a strong declaration of God's omnipotence. ${ }^{74}$ Furthermore, the resurrection of the dead is a

\footnotetext{
72 A. Clericuzio, 'God and the Physical World in Boyle's Thought', 1046.

${ }^{73}$ On the development of Boyle medical interests during the Oxford Period see R.G. Frank Jr., Harvey and the Oxford Physiologists: a Study of Scientific Ideas and Social Interaction (Berkeley and Los Angeles: University of California Press, 1980), esp. chaps. 5-6; B. B. Kaplan, Divulging of Useful Truths in Physick. The Medical Agenda of Robert Boyle (Baltimore and London: The John Hopkins University Press, 1993), chap. 2, esp. 68-76. On the development of Boyle's experimental programme see M. Hunter, Boyle: between God and science, chap. 7.

${ }^{74}$ Boyle Works, vol. 8, 299-300. The title page bore Gabriel's claim that 'Nothing is impossible to God' (Luke, 1: 37). On moral demonstration see Reason and Religion. Ibid., 281-82. On Boyle's classification of experience, The Christian Virtuoso. Boyle Works, vol. 11, 307-9. See also R. M. Sargent, 'Learning from Experience: Boyle's construction of an experimental philosophy', in Robert Boyle Reconsidered edited by M. Hunter (Cambridge: Cambridge University Press, 1994), 57-78, 65.
} 
miracle: as Boyle stated in his famous letter on ostensibly miraculous cures to Henry Stubbe, 'I am far from beleiving that any Mechanicall or Phisicall Hypothesis will make out those supernaturall Phaenomena without having recourse to the Miraculous Interposition of God'. ${ }^{75}$ We find similar statements in Reason and Religion: God can do 'many things that no other Agent can afford us any Examples of', in particular

the recollecting of a sufficient quantity of the scatter'd matter of a Dead humane Body, and the contriving of it so, that (whether alone or with some addition of other Particles) upon a reconjunction with the Soul, it may again constitute a living Man, and so effect that Wonder we call the Resurrection. ${ }^{76}$

Therefore, the Christian virtuoso should not lay aside reason to believe in bodily resurrection. When reason is enlightened by revelation, and we acknowledge that God is an omnipotent agent, believing in bodily resurrection is reasonable after all, even if reason cannot make the 'modus' out. ${ }^{77}$

In 'Possibility of Resurrection' Boyle claimed that he was defending the doctrine of resurrection in its 'strict and literal sense'. He argued that the particles of the resurrected body will be the same as those of which the dead body was composed. However, he admitted the task would have been easier if resurrection was understood in 'a greater latitude'. In the latter sense, soul was interpreted as the 'form' of body: this was Thomas Aquinas' solution to the problem of identity based on the Aristotelian notion of soul. ${ }^{78}$ Indeed, in Boyle's eyes the very scholastic concept of soul as a substantial form was somewhat unintelligible, as is apparent from the short digression on the scholastic doctrine of the development of the embryo contained in his Free Considerations about Subordinate Forms (1667). Boyle argued that this theory - which seemed to hold that embryo was imbued with the rational soul at an advanced embryonic stage - was somewhat inconsistent with the claim that soul is the 'Architect' of body, that is, its

\footnotetext{
${ }^{75}$ Boyle to Stubbe, 9 March 1666. Correspondence, vol. 3, 99. On the content of this letter and its place in the 'affaire Greatrakes', see N. H. Steneck, 'Greatrakes the Stroker', Isis, 73 (1982), 160-77 (167-68); M. Hunter, Boyle: between God and science, 149-52.

${ }^{76}$ Reason and Religion, 248.

${ }^{77}$ Ibid., 252.

78 On Aquinas' doctrine of formal identity see C. Walker Bynum, The Resurrection of the Body in Western Christianity, chap. 6, esp. 256-65.
} 
substantial form or organizing principle. ${ }^{79}$ However, Boyle was cautious about this issue and in Origin of forms and qualities he excluded the human soul from his critique of the notion of substantial form, though in the same work he criticized the scholastic view. Insofar as the Schoolmen taught that substantial forms cannot exist without matter, then their doctrine represented a problem for the immortality of the soul. ${ }^{80}$

In any case, in 'Possibility of Resurrection' Boyle separated the problem of the reunion of body and soul from the issues of material continuity and numerical identity. He deployed new weapons against old objections, resorting to medicine, chemistry, natural history and to the core of his corpuscular hypothesis. In the early 1660s Boyle was still interested in palingenesis. He asked Sir Robert Southwell for detailed information on Athanasius Kircher's 'vegetable phoenix' experiment, as is apparent from Southwell's response on March 1661. ${ }^{81}$ However, in 'Possibility of Resurrection' the experiment had lost the prominent role it played in 'Holy Scriptures'. Boyle mentioned the palingenesis of plants after he had discussed Paul's seed metaphor. He remarked that Paul's metaphor suggested 'the supposition of a Plastick Power in some part of the deceased Body'. The palingenesis or 'Resuscitation' of plants seemed to vindicate the same hypothesis, but Boyle preferred to avoid such an explanation: 'though the Resuscitation, supposing the matter of fact, may give no small countenance to our Cause; yet I do neither absolutely need it, or perhaps fully acquiesce in all the Circumstances and Inferences that seem to belong to it'. Arguably he became sceptical about that experiment, though he mentioned the testimony of two unidentified 'eminent Persons of my Acquaintance', as he put it, 'whereof one made the Experiment, and the

\footnotetext{
${ }^{79}$ Boyle Works, vol. 5, 453-54. As for the origin of soul, Boyle held the creationist view. He considered the creation of soul as a divine miracle. God created each individual soul and infused it in the embryo at a particular stage of his development, around the sixth week. Cf. Notion of Nature. Boyle Works, vol. 10, 553; Christian Virtuoso, Boyle Works, vol. 11, 301.

${ }^{80}$ See Boyle Works, vol. 5, 300, 343. Cf. also Notion of Nature. Boyle Works, vol. 10, 452 . On Boyle and the scholastic conception of soul see J. W. Wojcik, Boyle and the Limits of Reason , 125-26, 172.

${ }^{81}$ Southwell to Boyle, 30 March 1661. Correspondence, vol. 1, 452. Two years earlier Southwell had given details about the plant to Oldenburg: Southwell to Oldenburg, 20 October 1659, Oldenburg Correspondence, vol. I, 324. Athanasius Kircher performed the experiment of the 'vegetable phoenix' to celebrate Queen Christina of Sweden's visit to the Collegio Romano in 1656. The small plant he obtained was exhibited at the Musaeum Kircherianum: A. Mayer-Deutsch, "Quasi-Optical Palingenesis': The Circulation of Portraits and the Image of Kircher', in Athanasius Kircher: the last man who knew everything edited by P. Findlen (London: Routledge, 2004), 105-29, 107.
} 
other saw it made in his own Garden'. ${ }^{82}$ Boyle nonetheless reiterated the arguments based on the reduction to the pristine state he deployed in 'Holy Scriptures' to show how corpuscles 'may retain their own nature' in compounds and could be recoverable from them. Finally, he had recourse to 'instances of permanence of Corpuscles' drawn from 'Vegetables and Animals'. ${ }^{83}$ However, it should be noted that in 'Possibility of Resurrection' Boyle emphasized how those instances of material continuity could be interpreted as effects of the mechanical proprieties or 'affections' of matter:

Body and body being but a parcel, and a parcel of universal Matter Mechanically different; either parcel may successively put on forms in a way of Circulation, if I may so speak, till it return to the form whence the reckoning was begun, having only its Mechanical affections alter' $d$ '. ${ }^{84}$

Furthermore, Boyle touched on his views about the human body as a 'Hydraulopneumatical Engine';

A Humane Body is not a Statue of Brass or Marble, that may continue; as to sense, whole ages in a permanent state; but is in a perpetual flux or changing condition, since it grows in all its Parts, and all its Dimensions, from a Corpusculum, no bigger than an Insect, to the full stature of Man; [...] which could not happen but by a constant apposition and assimilation of new Parts to the primitive ones of the little Embryo. ${ }^{85}$

Besides material continuity, however, Boyle had to face another problem. If one rules out Aristotelian substantial forms and sets the seed metaphor aside, a new 'principle of

\footnotetext{
${ }^{82}$ It is worth noting that the experiment was also performed at the early Royal Society, but the fellows were not fully satisfied by it: see M. J. Gorman, 'From 'The Eyes of All' to 'Usefull Quarries in philosophy and good literature': Consuming Jesuit Science, 1600-1665' in The Jesuits: Cultures, Sciences, and the Arts, 1540-1773, ed. by J. W. O’Malley et al. (Toronto: University of Toronto Press, 1999), 170-89.

${ }^{83}$ Boyle Works, vol. 8, 305-8.

${ }^{84}$ Ibid., 308

${ }^{85}$ Ibid., 304. For Boyle's views on human body see Usefulness of Natural Philosophy II.I. Boyle Works, vol. 3, 310; Notion of Nature. Boyle Works, vol. 10, 540; Final Causes. Boyle Works, vol. 11, 148; The Christian Virtuoso II. Boyle Works, vol. 12, 472-73. Boyle seemed to espouse the preformist view in the 'Essay on Spontaneous Generation', although the matter is not clear. Boyle Works, vol. 13, 279-81. For Boyle's comments on current embryology and epigenesis see K. J. Ekholm, 'Harvey's and Highmore's Accounts of Chick Generation', Early Science and Medicine, 13 (2008), 568-614 (571).
} 
individuation', as Boyle put it, was needed. According to him, common sense, metaphysics and natural philosophy could not provide a clear notion of physical identity. Even in matters of biblical exegesis, the issue seemed to be unsettled. ${ }^{86}$ Nonetheless, Boyle was convinced that resurrection actually involved physical identity. He argued that the essence of matter, as Descartes had taught, was extension (Boyle added impenetrability), and he replaced substantial forms and plastic principles with the concept of texture:

And since the true Notion of Body consists either alone in its Extension, or in that, and Impenetrability together it will follow, that the differences which make the varieties of Bodies we see, must not proceed from the Nature of Matter, of which as such we have but one uniform Conception; but from certain Attributes, such as Motion, Size, Position, \&c. that we are wont to call Mechanical Affections. ${ }^{87}$

However, God's power only accounted for the last reunion between the same physical body and its former soul. According to Boyle, God himself had given evidence of his power through his 'Experiments' recorded in the Scripture, namely 'the raising again to life Lazarus and Christ' ${ }^{88}$ The union of body and soul was above reason, like God's modus operandi for bringing about bodily resurrection. Boyle placed the union of body and soul in this very life among the 'inexplicable things', because he could not conceive how an immaterial substance could act upon matter: there were no collisions so there was not a mechanical explanation. Boyle also considered Descartes' solution of the mind/body problem, but he could not persuade himself how the conarium could be the origin of motion. It is worth noting that Boyle placed the interaction between body and soul in the natural realm, but he had recourse to divine activity. Indeed, he interpreted mind/body interaction as the effect of natural but 'supra-mechanical' causes. ${ }^{89}$ Therefore, if the union of body and soul is 'inexplicable' in this life, the reunion between them was even more obscure. As Boyle declared in his later notes on miracles, the resurrection of the dead was one of the

\footnotetext{
${ }^{86}$ Boyle Works, vol. 8, 301.

${ }^{87}$ Ibid., 308.

${ }^{88}$ Ibid., 310.

${ }^{89}$ Things above reason. Boyle Works, vol. 9, 388: The Christian Virtuoso II. Boyle Works, vol. 12, 47778. On Boyle's views on the mind/body problem, P. Anstey, The Philosophy of Robert Boyle (London and New York: Routledge, 2000), chap. 8.
} 
Divine Miracles properly so call'd [...] because I see not how any Corporeal Power, or any other than a Divine one, could reunite to a Carcass or a dead Humane Body which for want of the Requisites absolutely necessary to Vital Union, was quite separated from it \& had passd into a new State, which makes the Resurrection of a Dead Man quite another thing incomparably more difficult than the Reviving of a Dead Dog or a Wither'd Tree. ${ }^{90}$

The 'redintegration' of the human body is a miracle, but it seems to be the sort of miracles which God performed 'without violating the fundamental laws of nature' by a 'fit, of yet but Mechanical, Preparation or Change of Disposition, in the Matter of the Bodyes wherein the Miracle is conceiv'd'. ${ }^{91}$ Instead, what made the resurrection of the dead a 'miracle properly so call'd' seemed to be the reunion between soul and body, an operation which could not be performed by 'any Corporeal Power, or any other than a Divine one'.

Boyle's treatment of the immortality of the soul and the resurrection of the dead provides us a notable instance of how he tried to reconcile his theological views with his commitment to mechanical explanations of natural phenomena, distancing himself from a materialistic form of mechanism, especially Hobbes', and showing that 'corpuscular' was not synonymous with 'somatical'. Boyle was also careful to preserve the reputation of the mechanical philosophy - in particular of his own variety, the corpuscular hypothesis - and that of Descartes. At the same time, however, he was scrupulous in establishing the boundaries of purely philosophical arguments in matters of religion, especially when mechanical philosophers put forward those arguments, as it was the case with Descartes' cogito argument.

\footnotetext{
${ }^{90}$ Cf. MS 198, fol. 39, in J. J. MacIntosh, Boyle on Atheism, 271.

${ }^{91}$ Cf. MS 199, fol. 125v, in J. J. MacIntosh, Boyle on Atheism, 270. On Boyle's classification of miracles see A. Clericuzio, 'God and the Physical World in Boyle's Thought', 1044-45.
} 